\title{
Constant consensus building: art and conflict in the ESMA museum and site of memory
}

\author{
Alejandra Naftal ${ }^{1}$ \\ 1 ESMA, Buenos Aires, Argentina \\ Corresponding author: Alejandra Naftal (naftalalejandra@gmail.com)
}

Published 12 January 2022

\begin{abstract}
This article describes the history, development and social role of the ESMA Museum and Site of Memory, which is located on the grounds of the former clandestine centre for detention, torture and extermination, in the intergenerational transmission of traumatic memories of the Argentinian dictatorship. The project is characterised by the cumulative effort of artistic expression, public debate, conflict and tension. Through the presentation of different artistic installations and plays, the article explains the focal function of art practices in spaces of memory that are strongly linked to a traumatic past, as well as how undertaking these practices can lead to the establishment of consensus.
\end{abstract}

\section{Key Words}

ESMA Museum and Site of Memory, State Terror and Human Rights Violations, Performing Arts and Conflict, Victimhood and Public Debate

\section{Introduction}

Between 1976 and 1983, Argentina endured a violent civic-military dictatorship that implemented state terrorism. According to current estimations, the military regime was responsible for more than 600 illegal detention sites across Argentina, 30000 disappeared detainees and thousands of political prisoners and people forced into exile. It also systematically stole children who were born to imprisoned women.

ESMA (Escuela Superior de Mecánica de la Armada) is located on a 17-hectare area in the city of Buenos Aires. It was a teaching institution for officers and NCOs of the Argentine Navy. During the dictatorship, the place operated as one of the most notorious concentration camps in the country. At ESMA, nearly 5000 men and women were detained and disappeared. Many of them were political and social activists, members of revolutionary organisations, workers, professionals, artists, entire families and members of the clergy. The list of crimes committed at ESMA is long, amongst them are kidnapping, torture and homicide.
The buildings where the clandestine centre operated is a design typical of the architecture from this area from the 1930s. It has three floors in the shape of a comb, sitting on a total area of $5,500 \mathrm{~m}^{2}$. Each area had a specific function during the years of repression. There were sections where torture, confinement and slave labour took place. However, the compound also comprised sections where repression agents operated, officers' bedrooms and a weekend house for the director and his family.

At the end of the dictatorship in 1983, the Argentine Navy surrendered ESMA to the newly-democratic state. The buildings were gutted of furnishings and left in a condition of total abandonment. Survivors' testimonies are the prevailing source of evidence to make sense of what took place at ESMA.

How should such former detention centres be treated now? This question has been asked time and again throughout post-dictatorship democracy. Responses have varied according to changing historical context and the collective construction of memories in the present that have worked to continually reframe it. Today, the ESMA Museum and Site of Memory serves a dual purpose. One 
the one hand, it provides material evidence in the ongoing trials for human rights violations committed here. On the other hand, ESMA's current cause and strategy have initiated a transformation of this site of horror and tragedy, into a space for memory transmission and the preservation of testimonies for future generations.

\section{The creative process}

In 2012, a multi-disciplinary team of professionals was formed to begin transforming ESMA into a Museum and Site of Memory. The new team's expertise comprised of museologists, architects, artists, researchers, journalists, designers, audio-visual specialists, computer scientists, poets and writers. In the preceding two years, the team had produced around two-hundred versions of the site's design and content. These proposals were presented to diverse sections of society, including victims and their families and friends. From this early stage on, ESMA's principle of interpreting and including diverse perspectives of the past guided all our efforts.

Public discourse about the treatment of sites connected with torture and abuse by the military junta has been varied and often contentious. At present, many sites have been established as spaces for memory, while at the same time, they are associated with traumatic violence and loss by their neighbouring communities and society as a whole. The discourse on what position such spaces should occupy is particularly shaped by the engagement between academics and museal specialists and those directly impacted by violence. Some have called for the demolition of clandestine prisons and torture centres, while others have regarded these spaces as spaces of mourning and emphasised their material emptiness.

The ESMA was established through dialogic engagement with all viewpoints on these questions. The result is the product of long-term facilitation of exchange of thoughts. While discussion has been a paramount element to the achievement of consensus, the ESMA was also made through close examination of a broad range of national and international archives, including documentation of legal cases, academic texts, news articles, literary and artistic works. Above all else, the testimonies of survivors have been central to the site's creation.

The ESMA Museum and Site of Memory was conceived for different audiences. The space needed to provide appropriate communication about this period for those visitors who were alive during the dictatorship and later generations. We also needed to provide resources that would meet the needs of local visitors, visitors from other parts of the country, as well as from abroad. The difficulty then, was to challenge this broad range of perspectives to actively engage in the painful and traumatic events that took place here. Our cause is summarised as the creation of a space in which 'those who are comfortable feel uncomfortable and those uncomfortable feel comfortable'. Our central purpose is to challenge those visitors who might have previously been indifferent and complacent. Our intention is that such visitors will engage anew in the past and also to become aware of the continuing need to remember this past in the present.

It was important that the museum's exhibitions and use of language were appropriate and do not resort to 'low blows' - melancholic or overt messaging that might distract or put off visitors. Language chosen for interpretation and information is consistently respectful and sober. We include distinct perspectives of events throughout to provide visitors with different viewpoints. It is our belief, for instance, that providing only details of traumatic events prevents any mechanism of identification and reproach - disabling reflection and meaningful action.

We have had to remain conscious of the fact that the past we share with visitors is very recent. Many relatives of the disappeared are alive, as well as survivors of violence that took place here. For this reason, the Museum is also a place of repair and reflection to living victims. Moreover however, the building in which we work continues to provide material evidence for ongoing legal processes against perpetrators of the violence that took place here. For this reason, it is vitally important that nothing about the building be altered or modified. This seeming limitation was added to by the fact that we had received a building that was completely emptied. The empty building and the stories of what happened there told by survivors formed our main message to the public.

What are the arguments against preserving a clandestine centre of imprisonment and torture? This question was a driving force in the process leading to the Museum's creation. Reconstruction of events, for instance, was a key ethical debate in our presentations to stakeholders. At the end of a presentation of the project for human rights organisation Madres de Plaza de Mayo, for instance, I recall that one member told us: "I want the people who visit the site to suffer the same as my son suffered. Let them feel the pain, the cold, the torture". Her words were followed by an intense silence amongst the group gathered to hear our presentation. While such a visitor experience would be unethical, we understood through such statements the expectation resting on the project to provide insight and defend this contentious past for survivors and victims' families.

For this reason, we reconstructed events through the testimonies of survivors as a foundation to interpreting these spaces. It was our conviction that we provide as many testimonies as possible for the same object or space, in order that visitors can piece together a whole picture of events from subjective viewpoints.

\section{The museum}

As it was a Museum, we understood that we represented in the social imaginary a place of truth and an authorised voice. It was, therefore, essential that we distinguished between historical documents and interpretations of the present. 


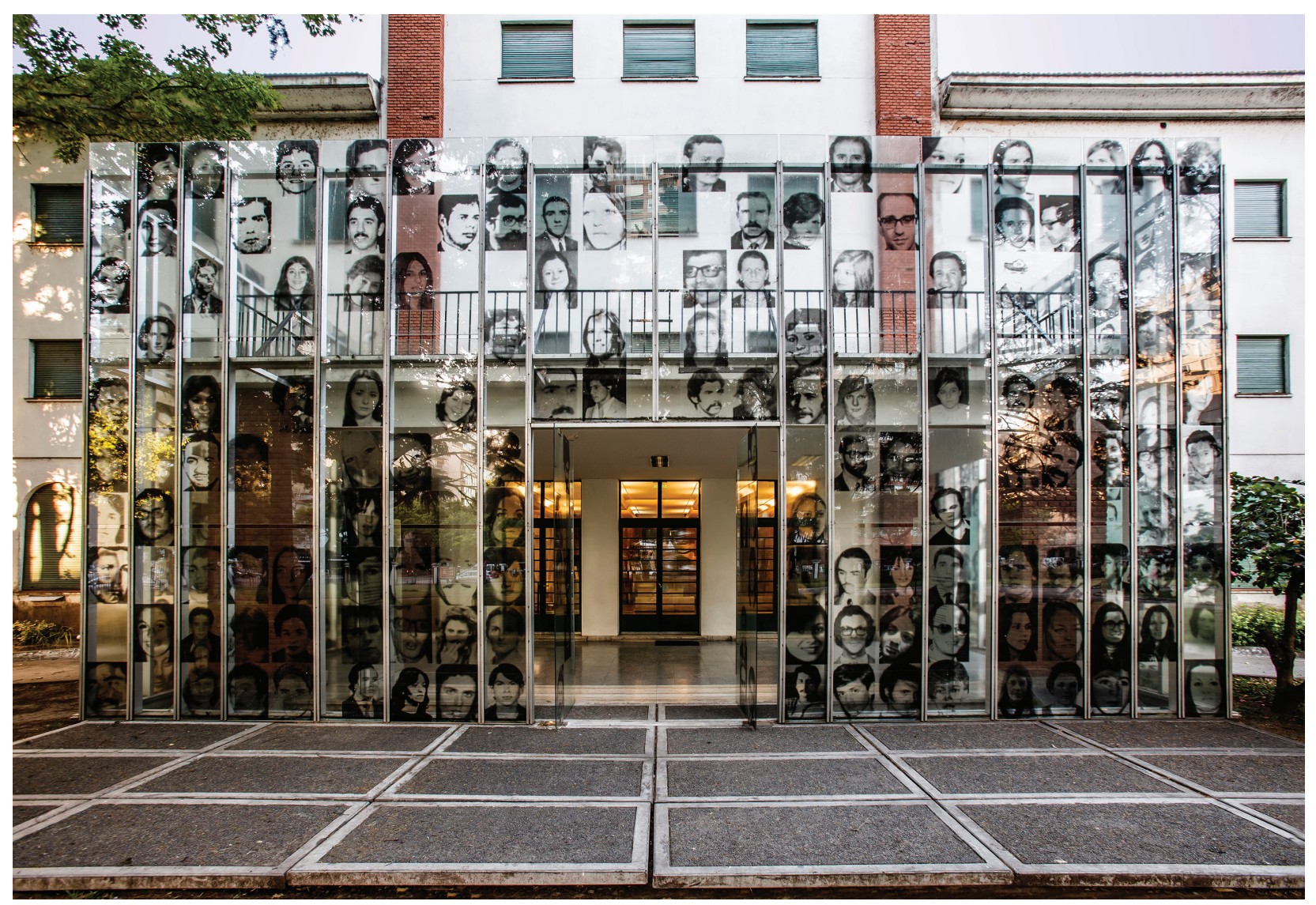

Figure 1. Museum façade. (ESMA Museum and Site of Memory).

The Museum consists of two museal devices in order to distinguish between historical fact and interpretation:

1. Traditional Historiographic Interventions: Panels featuring graphic prints, photos, documentary images, journalistic sources and testimonies. These devices provide historic information about different subjects from the military dictatorship.

2. Contemporary Experiential Interventions: Used in order to appeal to an affective reception amongst visitors. Methods included here work to stimulate curiosity and engagement about violent events and their symbolic import. These interventions, based on contemporary museographic devices, are made up of mapping, holograms, lighting, sounds and temperatures. Their objective is to transmit and approximate "the experience" in this place, both in the most aberrant aspects of the repressive dynamics and in the resistance of the people detained there.

Despite our working with these two categories of project design, there were still moments of tension and challenge in the process of reaching agreements over what the final site would represent. These challenges arose frequently from the highly personal nature of exhibition materials and the ongoing trauma of violence experienced by victim's relatives. Particularly problematic in some instances was the exhibition of photographs of victims that have also been used in public demonstrations and legal processes. For instance, a mother of a victim requested that a photograph of her daughter be removed from the Museum, because she did not want her daughter to be figuratively in the space where she was tortured and murdered. We respected this wish and it led to our thinking about how best to exhibit such photographs while respecting the views of family members of victims.

We designed a glass panel that would be printed with the photographs of victims, that is graphically dotted in order to trace but obscure their facial features and reveal them from certain angles. Displayed towards the entrance to the building, the panel generates a sense of scale of the number of victims. Secondarily, the viewer is able to see the faces of victims from afar, but is unable to make out their features when while walking towards the panel.

On another occasion, the grandmother of a victim told us: "Art, art!!! It's the best way to transmit this horrible experience to young people." (Hebbe de Bonafini, Presidenta de la Asociación Madres de Plaza de Mayo; August 2013; La Plata; Argentina). Bonafini's phrase guided us in the Museum's creative process. One of the first rooms visitors go through is the old entertainment hall for Navy officers. We do not have any testimonies from prisoners about this place. As it is a spot that has a lighter symbolic weight, we decided to use it to introduce visitors to the story they will go through both rationally and emotionally. We set up a screening of a film about the military dic- 


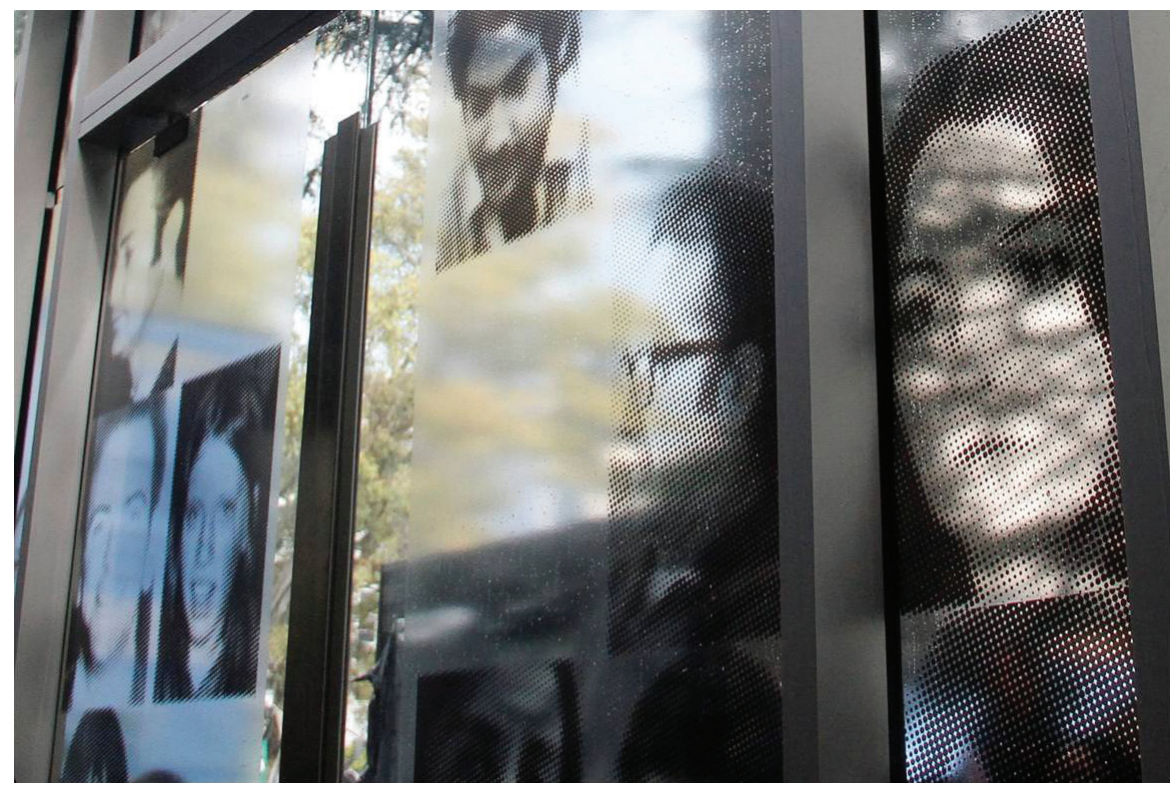

Figure 2. Museum façade. Detail. (ESMA Museum and Site of Memory).

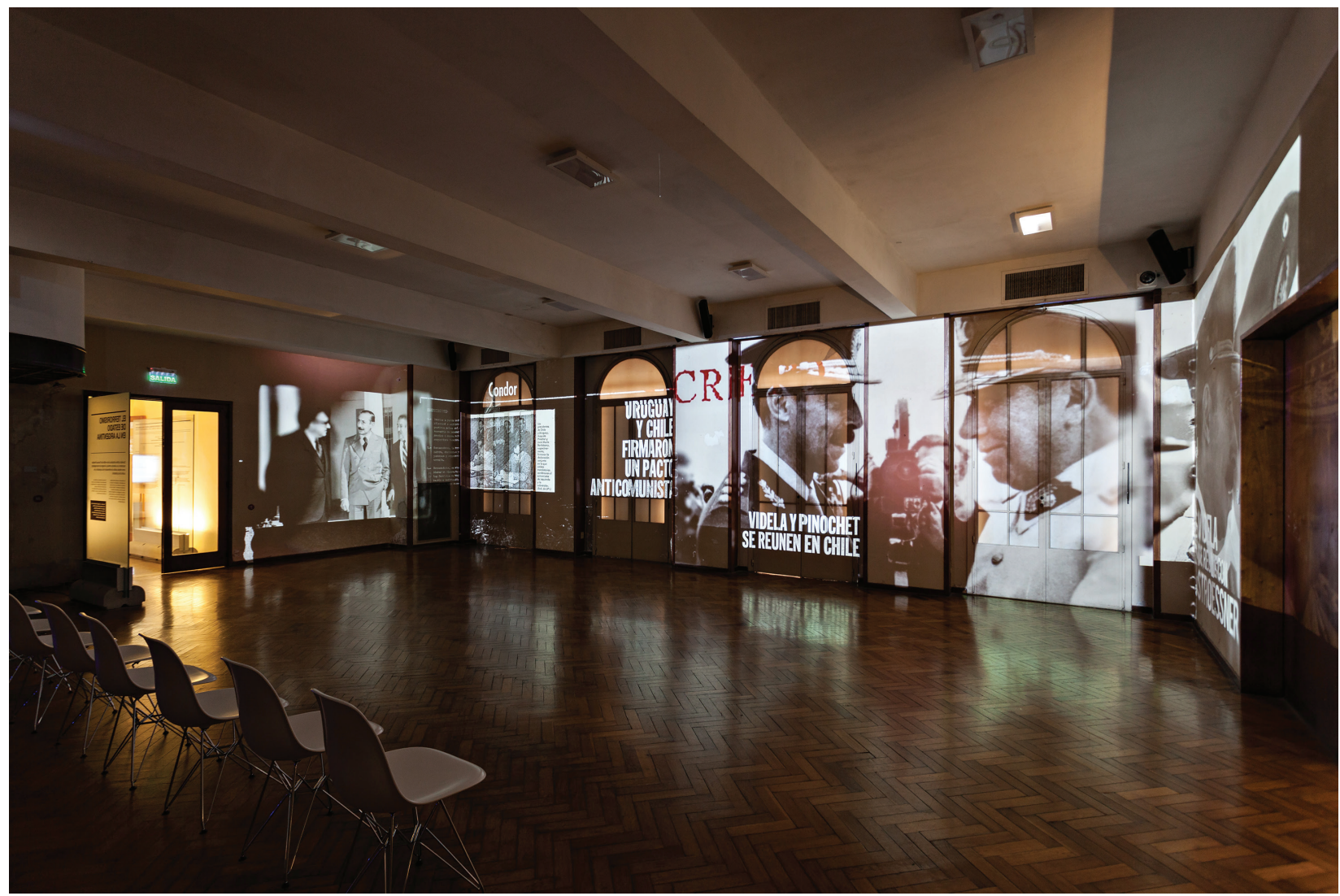

Figure 3. Context room. (ESMA Museum and Site of Memory).

tatorship that features archive footage providing context about the politics, economics and culture that led to the coup of 24 March 1976, the resistance to the dictatorship and the fight of human rights organisations and other sectors of society in the search for memory, truth and justice. The film reflects the way in which we curators wanted to use artistic interpretations in the Museum. We use art as a communicative and transmissive tool.
The third floor was the area of captivity, torture and slave labour. Along with the basement, these areas were the most complex places in the building due to their spatiality and their high historical and symbolic value. The visitor enters this section through the main staircase and through a narrow hallway.

Along the third floor, we installed a wooden walkway that serves several purposes. It preserves the original 


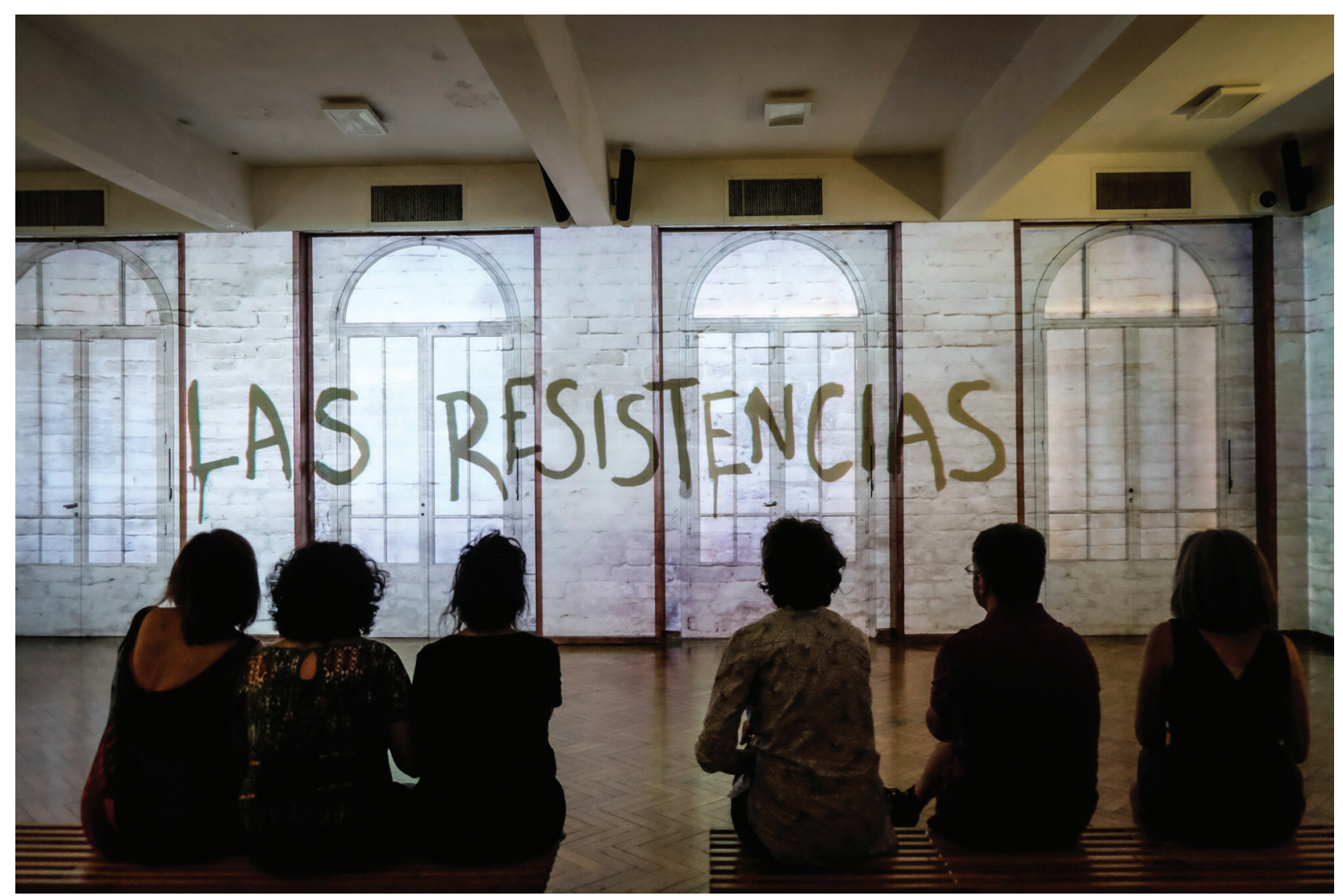

Figure 4. Context room. (ESMA Museum and Site of Memory).

floor, it guides the visitor and it hides the technical installations since we could not carry out any alterations to the building. The walkway guides the visitor closer and further away from the exhibits to evoke changing emotions. We decided to make the walkway out of wood, which is a warm, soft element. It helps the visitor get closer to the experience, but we also wanted to provide room for reflection and distance. Therefore, just as we did not rebuild a concentration camp, we were not going to build anything aesthetically unappealing. We employed beauty as an ethical and aesthetic concept that would contribute to our goal of transmitting a legacy and a memory.

The "El Dorado" room originally was a ceremonial hall. During the military regime, the Intelligence Centre was established here. Here, kidnappings were planned, the information obtained from prisoners in torture sessions was analysed and decisions about their life and death were made. This is where the files containing the information of each of the detainees and their political organisations were kept. The dictatorship's propaganda campaigns were also developed here.

The El Dorado room is the last room the visitor enters and we developed an audio-visual intervention about ongoing trials of perpetrators. They are portrayed in photographs taken from military files of the dictatorship, which were then replaced by photos of them in court. These pictures are leaning on the floor. This is an allegory of the action carried out on 24 March 2004, the anniversary of the 1976 coup d'état, a date Argentina established as a na- tional day of remembrance. On this day, President Néstor Kirchner took down the picture of the repressor Videla from the wall of the Military College.

\section{Art at ESMA}

Five years after it opened, the ESMA Museum and Site of Memory has established itself as a place of active participation. To this day, it has received more than 400,000 visitors from diverse backgrounds. They include high school students, university students, tourists, officials, politicians and representatives from other countries.

Initially, the curators had a different vision considering the role of artistic expression in the exhibition. However, we adapted our ideas accordingly to achieve consensus. This happened with the basement of the building, which is perhaps the place with the greatest symbolic load, since it was the area where brutal torture was inflicted and also the last place the detainees saw before the "transfers", a euphemism used to describe the ultimate fate of the prisoners. In that basement, prisoners selected for death flights were lined up, stripped naked and given an injection of pentothal to numb them. They were then loaded on to trucks and taken to military airports. There, they were moved into aeroplanes and finally thrown alive into the sea.

In this dark place, we intended to put a large installation that would take up almost all the space, a rock, suspended from the ceiling, opposed to another rock suspended on the 


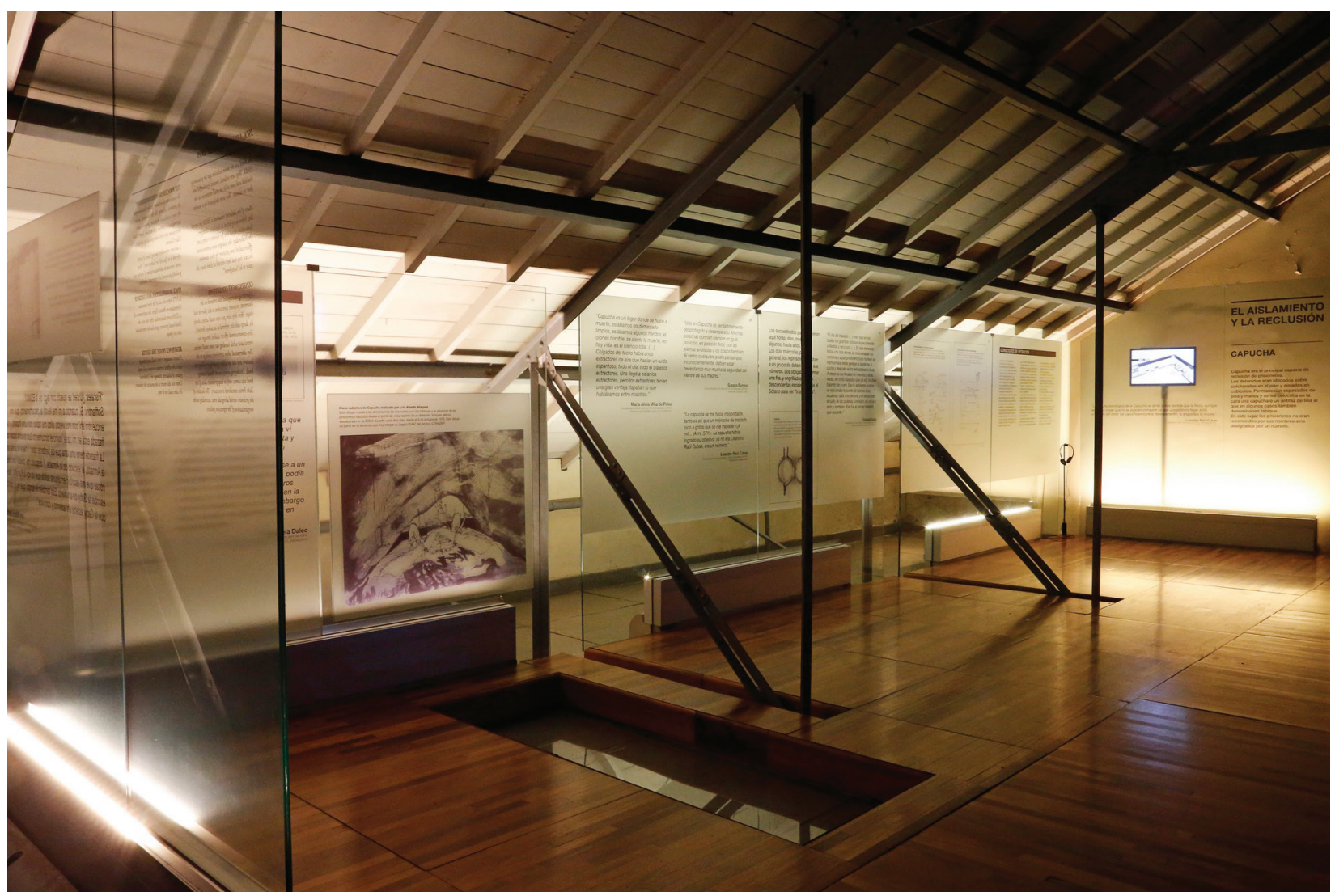

Figure 5. Third floor, Capucha. (ESMA Museum and Site of Memory).

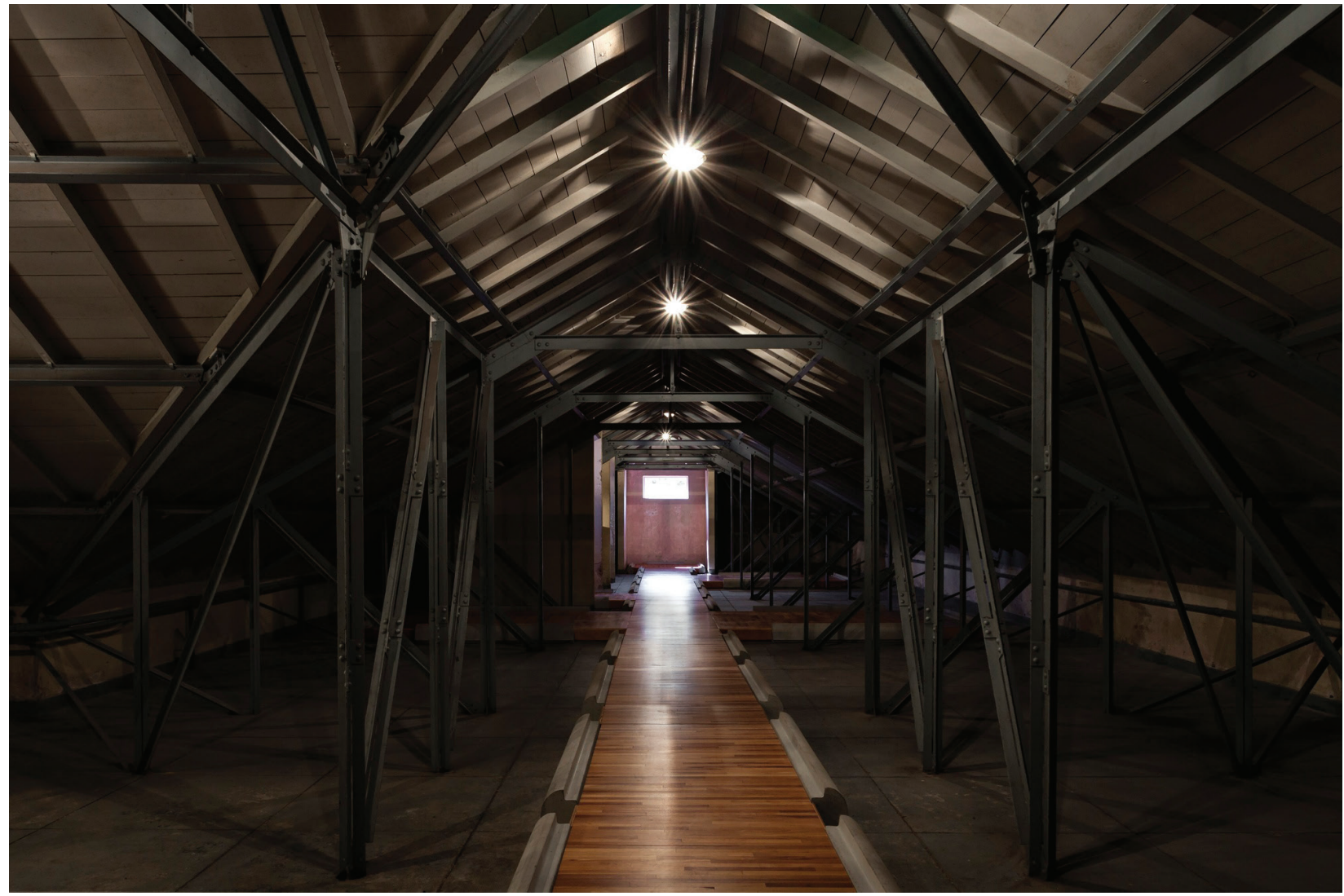

Figure 6. Third floor, Capucha (ESMA Museum and Site of Memory). 


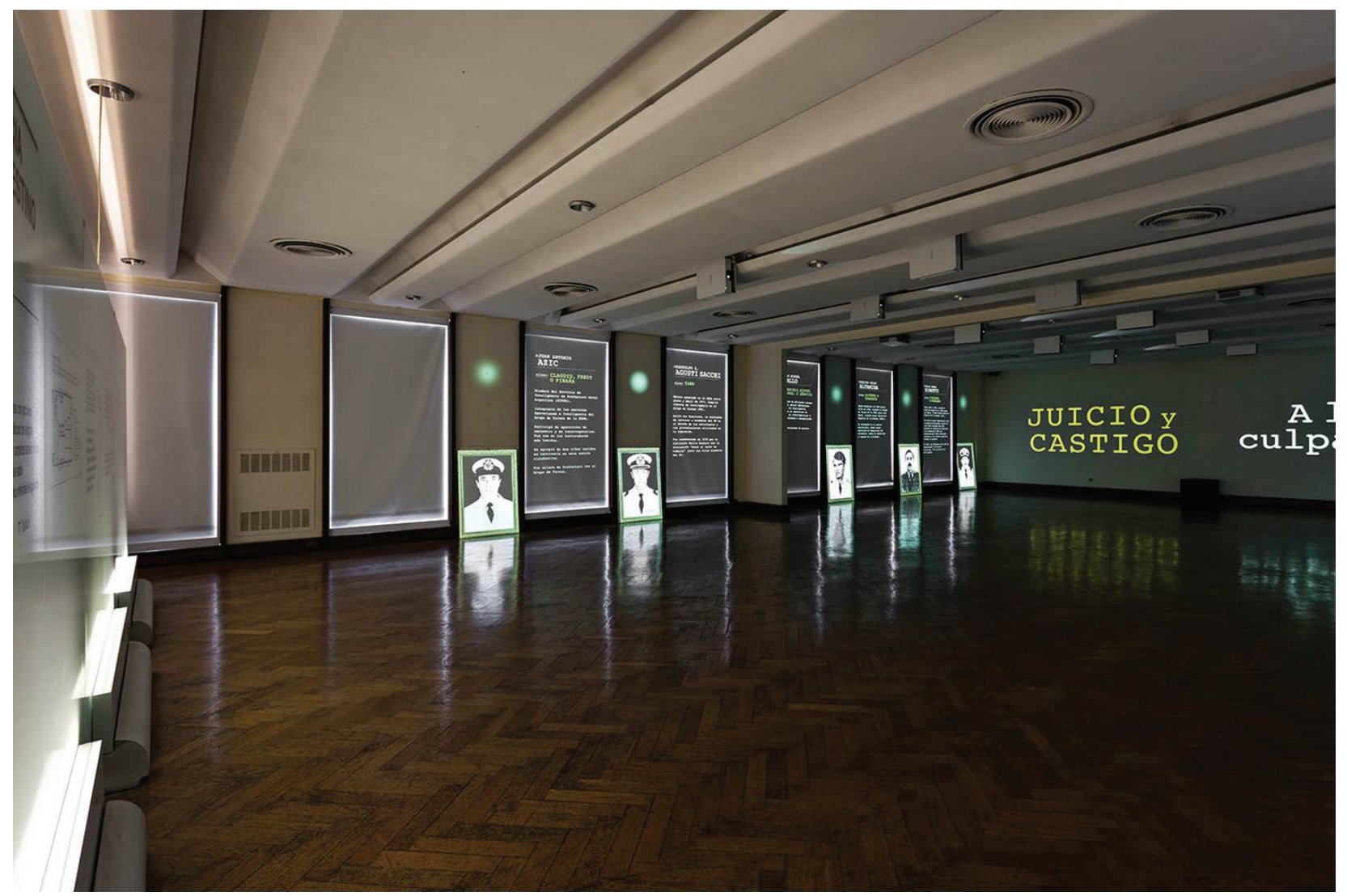

Figure 7. "Dorado" room. (ESMA Museum and Site of Memory).

floor. Between them, we wanted to place a rainfall of water that came out from 30,000 pores and project the only photos we have of this place during the dictatorship taken by a former detainee. However, we were not able to reach consensus about this installation as it was unacceptable to several survivors and victim families. This exemplifies that the tensions between artistic languages and the vision of the victims can be contradictory and ambivalent. Therefore, we say that the Museum is an ongoing project. This is fruitful for the connection between the educational and emotional realms that are present in the stories we wish to tell.

I want to comment on some concrete experiences of artistic articulation, where these tensions were strong. One of the proposals of the project was to apply our focus on consensus to explore new channels and languages to help engage audiences and transmit what happened. This resulted in heated and fruitful exchanges between academics, the Museum and the artists. We treated various questions, such as what was at stake for each stakeholder? When and how should they intervene? How should we combine the artistic, academic and institutional visions on curating?

\section{Performing arts}

We were curious to find out whether we could integrate the performing arts and innovative curatorial practices to create a dialogue with art galleries and other sites of memory to come up with new questions. In recent years, ESMA developed diverse projects to explore languages that help broaden the audiences beyond the communities around the direct victims. In the month of November 2019, the Museum featured the Memory and Performance Art series.

ESMA hosted a performance for the first time, namely Araceli Arreche's The Voices of the River. It was performed by a collaboration of graduates of the Metropolitan School of Dramatic Arts (EMAD) and the University of San Martín (UNSAM). The play describes some of the darkest aspects of Argentina's history through a fictional encounter in the depths of the Río de la Plata between Leopoldo Lugones, Roberto Arlt and the French nun and death flight victim Alice Domon. The Voices of the River seeks to challenge viewers to re-think through art how the past continues to resonate in our present. Director Martín Paglione wrote to the Museum director's office in his proposal for the play how he intends to combine the locality of ESMA with the content of the play by integrating a tour through the Museum's spaces. Based on this proposal, we worked together for two months during which the Museum specified its requirements of not altering any area of the exhibition and maintaining an atmosphere of respect and lightness.

We aim to use the space, based on its history and its connection with the play. We will begin by welcoming the public at the reception with some opening words. We 


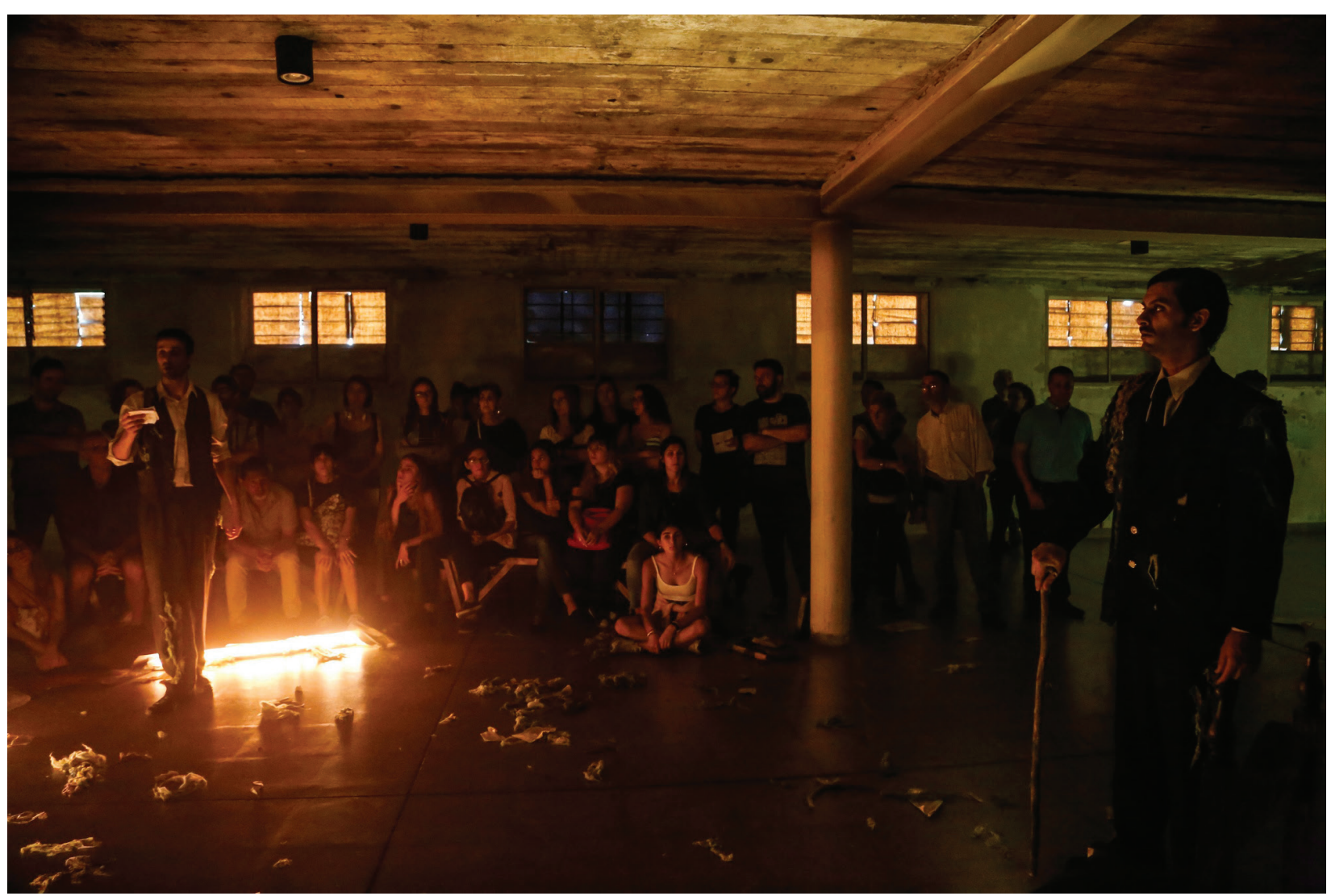

Figure 8. Voices of the River (ESMA Museum and Site of Memory).

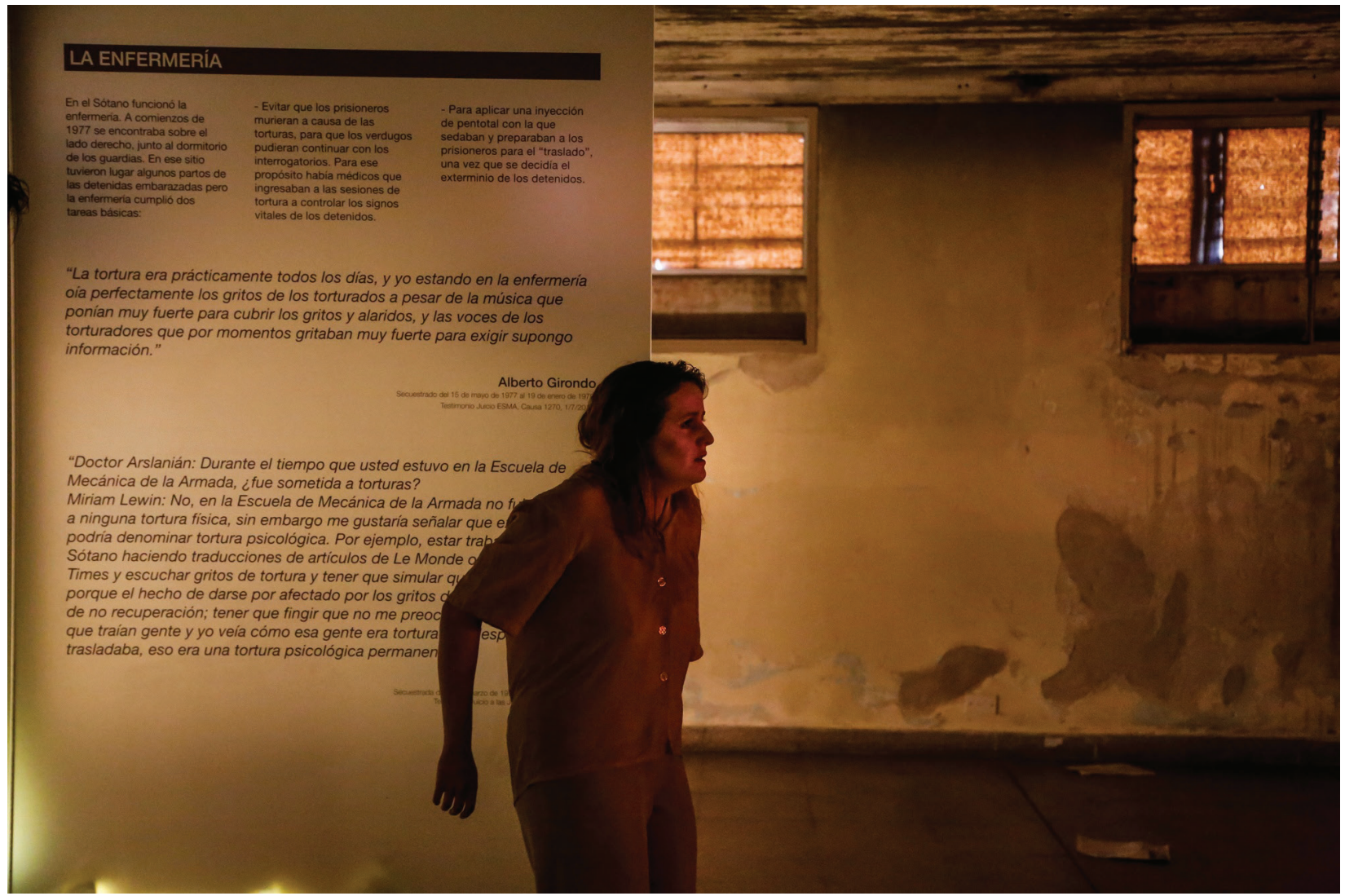

Figure 9. Voices of the River (ESMA Museum and Site of Memory). 


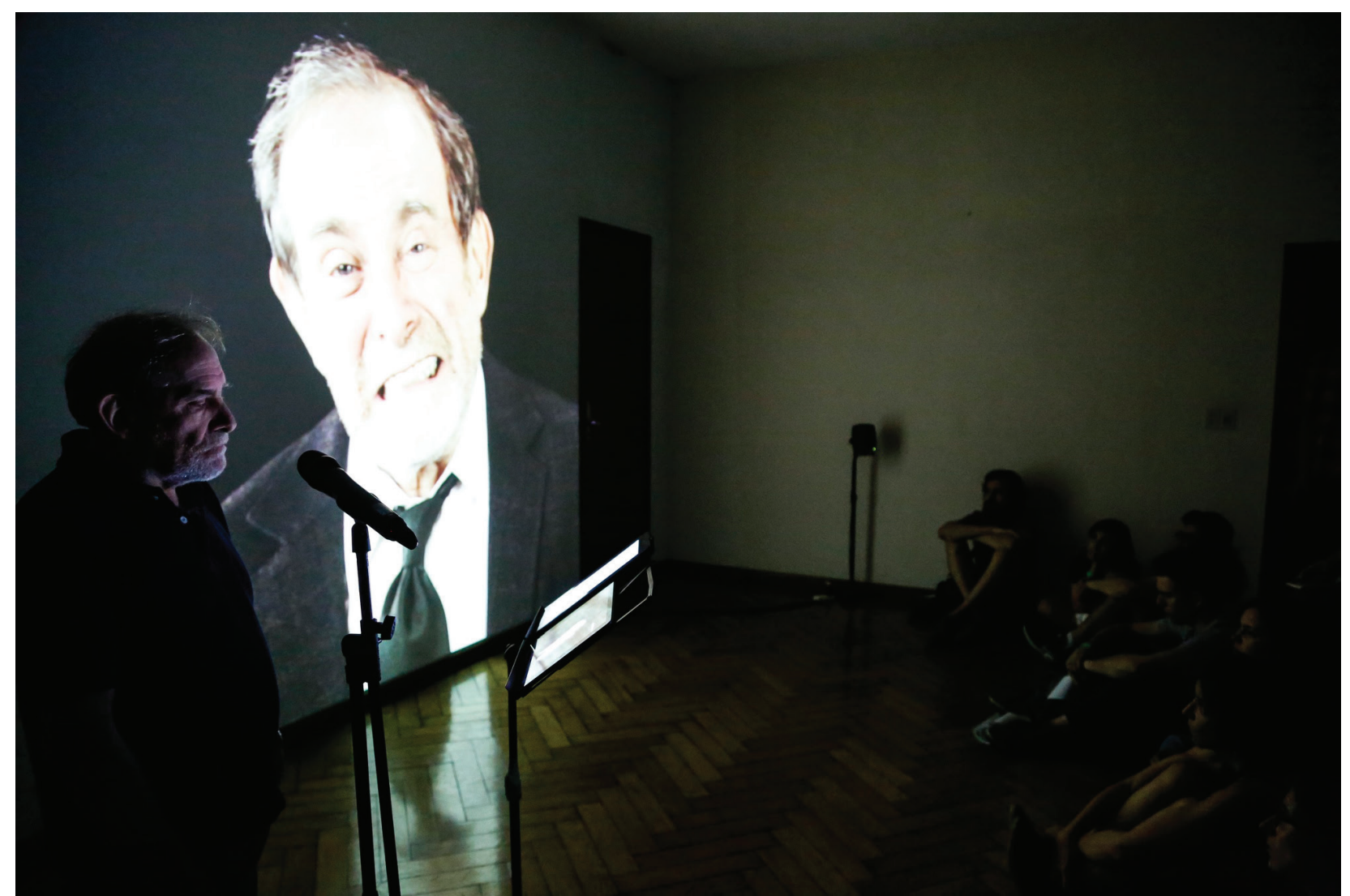

Figure 10. The Impossible Scene (ESMA Museum and Site of Memory).

will move towards the historical context, where the public will settle on the seats and the floor to watch the full screening. Once the video is over, the first act of the play begins. Then we will move on to the ESMA History sector, where the tour continues and we will proceed to the basement. There will be another section of the play. We will immediately go up to the golden room, where the rest of the play is performed (Martín Paglione, November 2019; Buenos Aires, Argentina).

In that same month, two other plays were performed at ESMA. The Impossible Scene was performed by Polish visual artist and theatre director Wojtek Ziemilski in collaboration with Argentine playwright Ruben Szuchmacher, during the artist's stay at the ESMA Museum and Site of Memory as part of the research project Staging Difficult Pasts of the University of London. The performance examines how theatres and museums influence the public memory of difficult pasts through situating them in narrated scenes. This was an international exchange programme between artists, curators and cultural institutions from Poland, Lithuania, Spain, Argentina and the UK. The second performance was the play Adjournment. A Guide for Audiences of Crimes Against Humanity, by writer Félix Bruzzone $\mathrm{Y}$ and French-Argentine attorney, actress and writer Mónica Zwaig. This play tells the story of an unexpected romance in the context of legal trials for crimes against humanity.
The first performance took place at the "Admiral's House" room, an area that functioned as a weekend family retreat for the head of the clandestine centre. Ziemilski's play raised questions about the perpetrators. Do they cry? Do they regret it? Can they cry? Question about the soldiers' minds that made up the armed forces were difficult to accommodate in the Museum. Their voices have mostly been eliminated from the public sphere and many are currently in prison. However, the institution they were part of has never issued an institutional apology for their crimes and their voices are still inaudible in places like the Museum. Here, their representation is limited to their role in the repression and the crimes they committed. The artists were trying to find another way to access their stories through making them human. Ziemilski stated during the premiere:

It seemed to me that there was something crucial in the idea of being able to imagine something that is an Other. What is there? A human Other who does not correspond to the idea of being human we have. That is why I wanted to represent what exists on the other side to open something else. It was easy for me to do this while I was away, but when I got here, the story had its weight, its difficulties. When I started working, it became heavier, more difficult. Each step, each day, each decision became more difficult. I tried to establish a certain contact with the public, an empathy. Being here, in this space, I did not find another way to approach the subject. Afraid of you, 


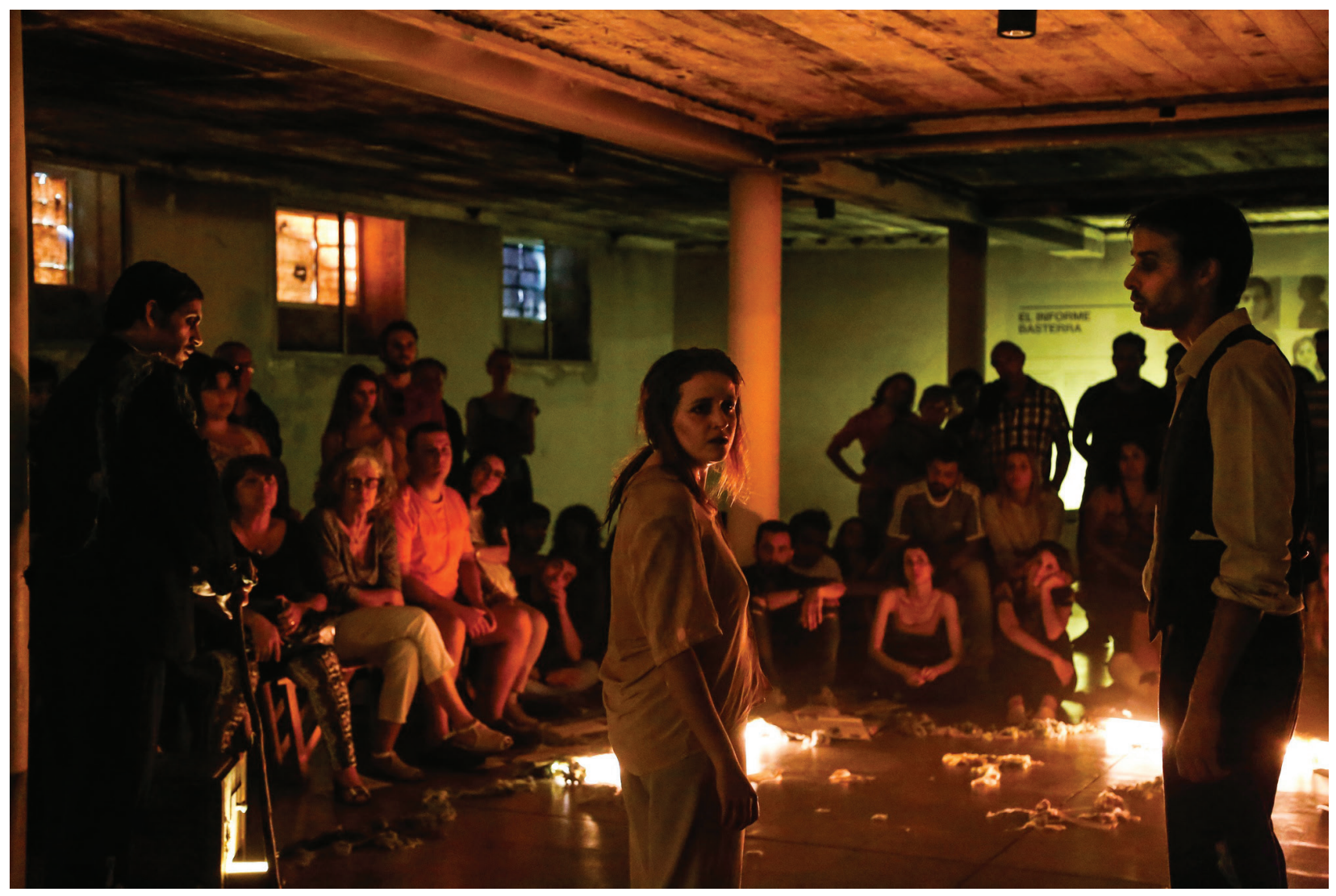

Figure 11. Voices of the River (ESMA Museum and Site of Memory).

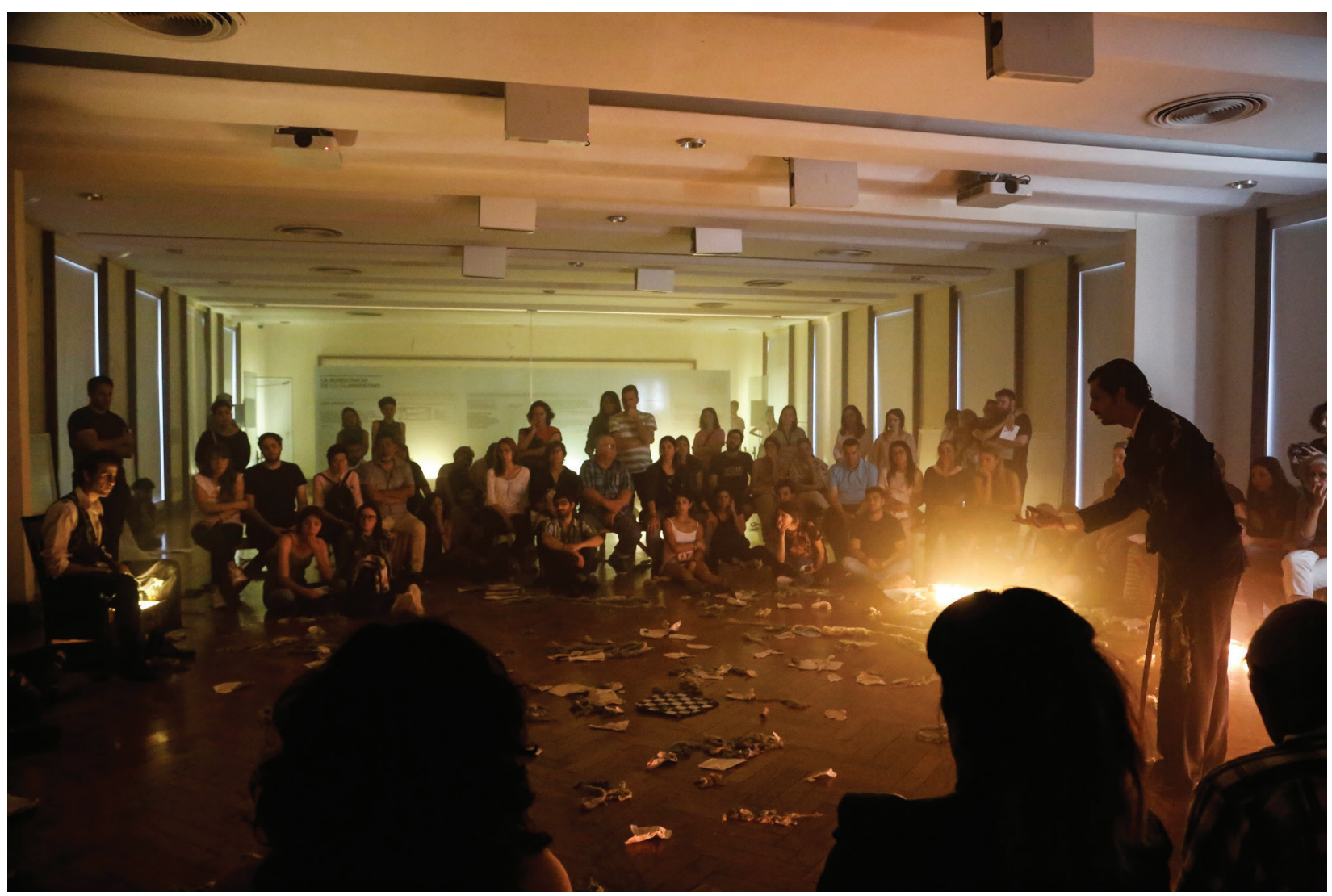

Figure 12. Voices of the River (ESMA Museum and Site of Memory). 


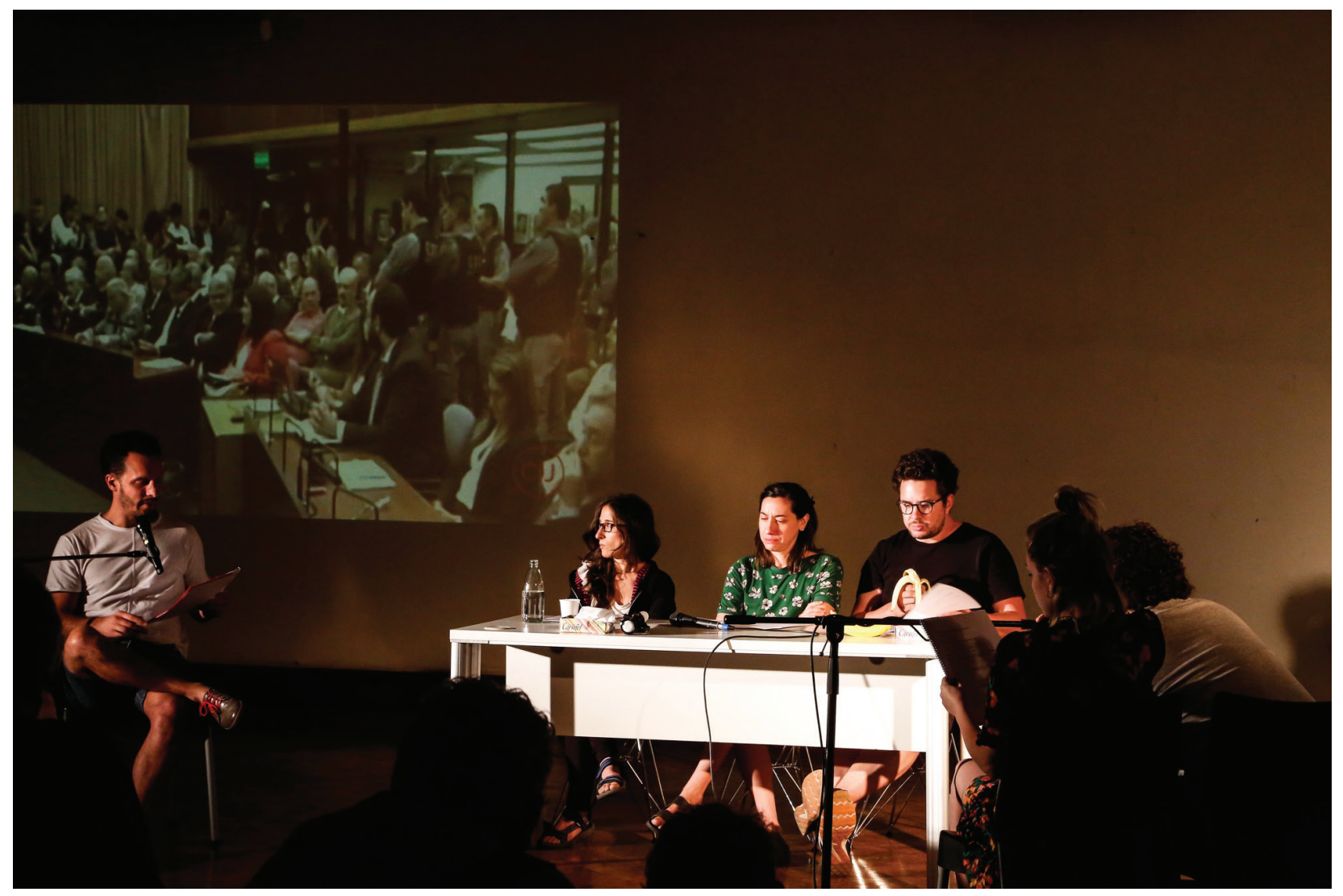

Figure 13. Adjournment (ESMA Museum and Site of Memory).

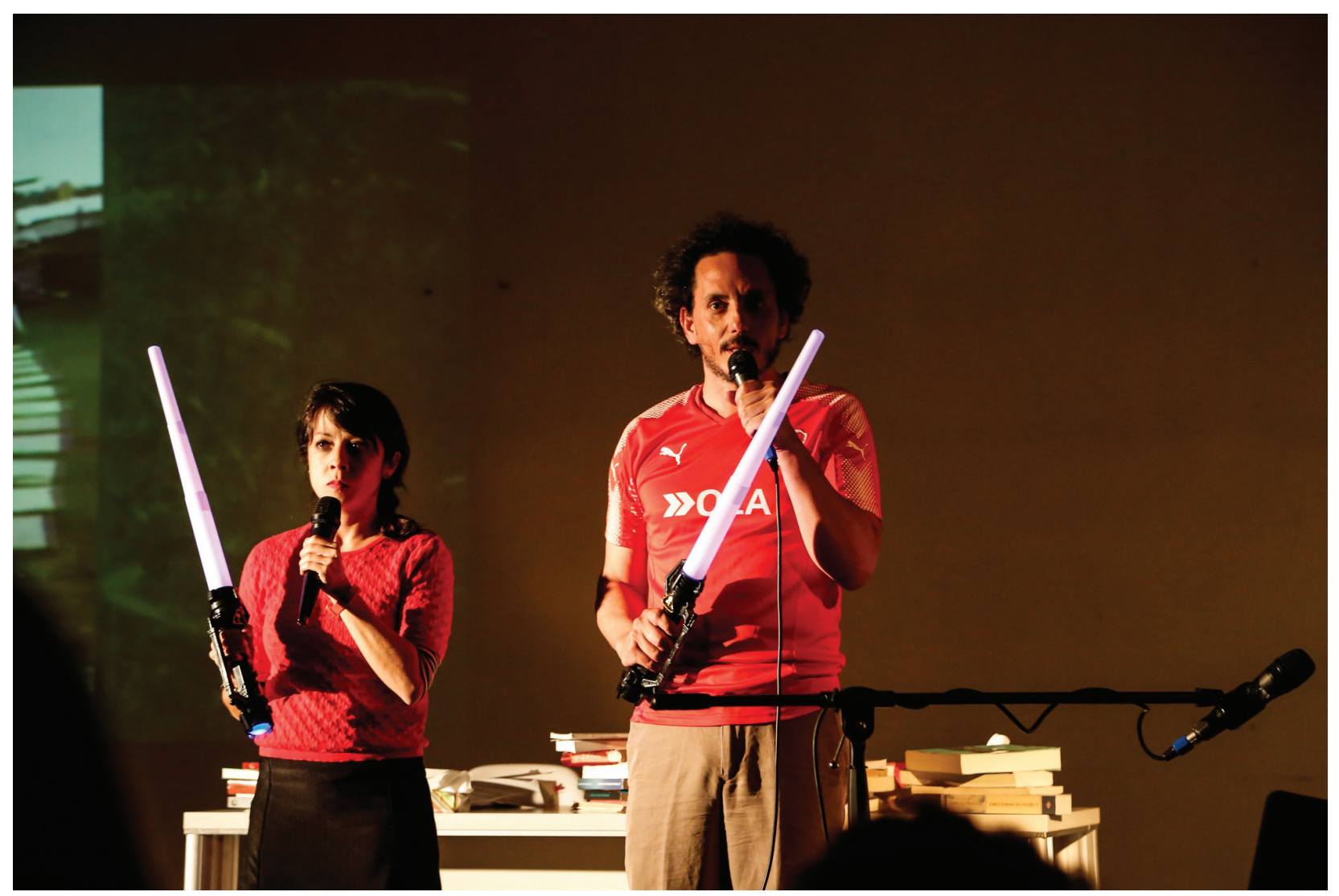

Figure 14. Adjournment (ESMA Museum and Site of Memory). 
of your thoughts and feelings. (November 2019, Buenos Aires, Argentina)

Ziemilski spent three weeks in Argentina and he spent a year studying the local characteristics of state terrorism. He asked questions and thought of different proposals for the play. Should he name the perpetrators or not? Who were they, anyway. Actor Rubén Schumajer recalled that it is a subject that is very close to him. The son of a Polish immigrant, his cousins were killed in World War II concentration camps and he has relatives who disappeared at ESMA. He said: "I usually refuse to represent these themes. It is the first time I have done it, but having done this play, having to play a perpetrator who tries to cry at the hand of Wojtek (Ziemilski) was a very important experience that I am grateful for." (Noviembre 2019, Buenos Aires, Argentina)

The second performance, Adjournment, took place at the Golden Room, home of the ESMA Task Force's intelligence headquarters, which today features an audio-visual installation that describes the Argentine path to justice, from 1983 to this day. The play is a testimony to a real meeting between Felix and Mónica, two people who speak different languages and yet agreed on the fact that it is possible to talk about trials for crimes against humanity without biting one's lips or crying. Adjournment proposes a tour through the delirious, incomprehensible and absurd areas which the judicial body imprints on the darkest events of recent history.

Monica Zwaig said about the experience of doing the play in what used to be one of the most notorious concentration camps: "There was laughter, and I felt strange about hearing so many laughs here. But I think I kind of liked it." (November 2019) Félix Bruzzone added: "We had an expectation of starting very low, not just because we were doing it in this place, but because the audience came from another tour, already charged, but curiously enough, they quickly responded to our play. I was very surprised that it happened here. It seems good to me that we were able to carry out the work this way and that this space can welcome this type of pieces." (November 2019)

\section{Conclusion}

To what extent do art performances allow us to develop new ways of transmitting stories? We have been asking such questions ever since the first scenes were staged at ESMA and also posed them publicly. We are going to evaluate together with the project researchers, the various sectors associated with the search for consensus as we always do to find out whether this is effective or good or something that enables us to continue thinking and exploring new languages to re-think about what happened, facing the need to re-evaluate ourselves to be - and to become - better. Through these activities we managed to engage audiences who had never been near the Museum, mostly artists and drama students.

A few days after these events, some very intense debates took place amongst the members of the Museum's Advisory Board, which is made up of representatives from human rights organisations and victims. One of the most important opinions again questioned the scope of what should be done in the Museum. These were mostly issues related to artistic manifestations, some of them were almost turning the site into a sacred temple whose only objective was to remember and pay tribute to the disappeared detainees of ESMA. This debate continues because memory is a collective construction of the present that is in a constantly dynamic state.

To be able to participate in Project SPEME and share academic and professional experiences with our colleagues from Amsterdam, Bogotá, Bologna and Buenos Aires is an important contribution to the Museum and to these debates. This article has provided a professional perspective on the challenges the ESMA Museum and Site of Memory faced in representing Argentina's recent history. Through extensive debates with artists, relatives of victims and the public, ESMA strove to establish consensus about how the past should be represented here. The interior of the museum itself, but also performances organised here and artistic installations are geared towards unsettling accepted truths about the military dictatorship and stimulate reconciliation. 